\begin{tabular}{|c|c|c|}
\hline NA & $\begin{array}{l}\text { Науковий вісник НЛТУ України } \\
\text { Scientific Bulletin of UNFU }\end{array}$ & \begin{tabular}{|l|l} 
(c) (i) ISSN 1994-7836 (print) \\
BY ISSN 2519-2477 (online)
\end{tabular} \\
\hline НАTப & https://doi.org/10.15421/40280710 & $@ \bowtie$ Correspondence author \\
\hline & $\begin{array}{l}\text { Article received } 12.07 .2018 \mathrm{p} \\
\text { Article accepted } 26.09 .2018 \mathrm{p} .\end{array}$ & $\begin{array}{r}\text { V. P. Masalskiy } \\
\text { vlad.masalskiy71@gmail.com }\end{array}$ \\
\hline & УДК 631.96:551.524:502.11 & \\
\hline
\end{tabular}

В. П. Масальський ${ }^{1}$,. І. Кузнєцов²

${ }^{1}$ Білоиерківський національний аграрний університет, м. Біла Церква, Україна

${ }^{2}$ Національна академія керівних кадрів культури і мистещтв, м. Київ, Украӥна

\title{
ВПЛИВ ПАРКОВИХ НАСАДЖЕНЬ НА ТЕМПЕРАТУРНИЙ РЕЖИМ УРБАНІЗОВАНОГО СЕРЕДОВИЩА
}

\begin{abstract}
Наведено результати досліджень із впливу міських насаджень на температурний режим урбанізованого середовища. Встановлено, що різниця температур повітря на різних об'єктах озеленення залежить від розмірів зеленого масиву; чим більшим $\epsilon$ деревний масив, тим більшим $\epsilon$ його вплив на температуру повітря. З'ясовано, що найбільший вплив на температуру повітря мають стиглі й перестиглі насадження заввишки понад 20 м і дерева зі щільною широкорозкидистою кроною. Таким вимогам найбільше відповідають саме аборигенні види деревних рослин. Порівняно з іншими об'єктами озеленення, різниця температур, відносно контролю, у дендропарку становила 12,7 \%, тоді, як на інших об'єктах цей показник не перевищив $6,9 \%$. Тобто, великі, вікові деревні масиви, створені аборигенними видами, найбільше впливають на зниження температури в літній період. За результатами проведених досліджень встановлено пряму залежність впливу розмірів парків на температурний режим. Чим більший деревний масив за площею, тим більша різниця температур між парком та відкритим простором або вулицею. Доведено, що деревні масиви (парки) доцільно створювати з аборигенних видів декоративно-листяної (тіньової) групи дубового типу. Відзначено, що чим більша площа деревного масиву, тим на більшу відстань поширюється вплив насаджень на температурний режим прилеглої території.
\end{abstract}

Ключові слова: урбанізація; комфортні умови; мікроклімат; температурний режим; площа деревного масиву; теплосприйняття; species of aboriginal.

Вступ. Постійне зростання процесу урбанізації призводить до розростання населених місць, і як частина цього процесу іде забудова з використанням різних будівельних матеріалів. Ці матеріали зазвичай мають низьке альбедо і тому мають значне теплове випромінювання. До того ж діяльність промислових об'єктів та постійне зростання кількості автомобільного транспорту підвищує температуру міського середовища. У таких умовах надзвичайно важливо знизити температурні показники і максимально наблизити їх до "комфортних", особливо під час літньої спеки (Kalitin, 1935; Landsberg, 1983; Klein, 1947; Blum, 1954).

Актуальність теми дослідження. В умовах урбанізованого середовища створення комфортних умов для життя, роботи і відпочинку людей є пріоритетним завданням.

У цьому питанні найважливішим є створення зелених насаджень у населених пунктах. Адже зелені насадження покращують мікроклімат: знижують критичні температури, уповільнюють або створюють рух повітря, знижують рівень шуму, збагачують повітря киснем і фітонцидами, захищають від газу і пилу, іонізують повітря тощо. Відомо, що об'єкти озеленення мають не тільки різне призначення (загального користування, обмеженого користування і спеціального призначення), а й по-різному впливають на екологічні зміни, які відбуваються в міському середовищі. В умовах посиленого процесу урбанізації, дослідження впливу насаджень на температурний режим, а також розроблення пропозицій щодо покращення цього показника в міському середовищі є надзвичайно актуальними для створення комфортних умов для життя, праці й відпочинку мешканців населених пунктів (Adamenko, 1975; Blaivas, 197; Воbokhidze, 1965; Rodychkyn, 1977).

Мета $і$ завдання дослідження. На підставі проведених досліджень встановити залежність температури урбанізованого середовища від площі деревного масиву впливу.

Умови дослідження проводили в Білій Церкві у: дендрологічному парку "Олександрія" площею 400,7 га (заміри проводили в балці "Лев", розташованій у 500 м від меж парку і міста), парк культури і відпочинку "Шевченка" площею 6 га, сквер біля Білоцерківського національного аграрного університету площею 1 га, двір житлового кварталу (є намет від крони старих дерев), міська вулиця (Ярослава Мудрого).

Об'єктом дослідження була температура повітря на об'єктах озеленення, різних за площею.

Методика проведення досліду зводилась до одночасні замірів температури на різних об'єктах озеленен-

\section{Інформація про авторів:}

Масальський Владислав Петрович, канд. біол. наук, доцент, кафедра садово-паркового господарства. Email: vlad.masalskiy71@gmail.com

Кузнєцов Сергій Іванович, д-р біол. наук, професор, кафедра дизайну середовища. Email: cedrusk90@gmail.com

Цитування за ДСтУ: Масальський В. П., Кузнєцов С. І. Вплив паркових насаджень на температурний режим урбанізованого середовища. Науковий вісник НлтУ України. 2018, т. 28, № 7. С. 49-52.

Citation APA: Masalskiy, V. P., \& Kuznetsov, S. І. (2018). The impact of park plantings on the temperature regime of the urbanized environment. Scientific Bulletin of UNFU, 28(7), 49-52. https://doi.org/10.15421/40280710 
ня $з$ різною площею, щоб встановити різницю температур у різних точках міста залежно від розміру масиву.

Результати дослідження. Як відомо, систему озеленення населених пунктів складають: об'єкти озеленення загального користування, об'єкти озеленення обмеженого користування та об'єкти озеленення спеціального призначення.

Насадження загального користування: парки, сквери, бульвари, набережні $є$ найдоступнішими і найпоширенішими. Незважаючи на те, що всі ці об'єкти є об'єктами загального користування, вони є різними за функціональними призначеннями, за площею, за принципом створення, і відповідно за принципом підбору деревно-чагарникової рослинності. Якщо бульвари і набережні є "зеленими артеріями", через які свіже повітря надходить від прилеглих територій у місто, то парки є саме тим місцем, де відбуваються екологічні зміни покращується мікроклімат.

Як відомо, мікроклімат - це клімат живого організму в тому місці, де він перебуває. У нашому випадку йдеться про фітоклімат, тобто той клімат, який створює рослинний намет (деревний, чагарниковий чи навіть трав'яний), а точніше, конкретна рослинна асоціація (Luntc, 1974).

3 усіх екологічних факторів на здоров'я і відчуття людини найбільше впливає температура навколишнього середовища. Відомо, що насадження знижують температуру (Blaivas, 1972; Kucheriavyi, 2008; Luntc, 1974; Rodychkyn, 1977). Встановити різницю температур у межах міста на різних об'єктах озеленення було нашим завданням. Заміри проводили в межах одного міста (Біла Церква) одночасно на 5 об'єктах озеленення, різних за площею. Як контроль використовували вимірювання температури на відкритому просторі (на полі) в 0,3 км від насаджень. Для замірів використовували електронні термометри зі шкалою ділення $0,1^{\circ} \mathrm{C}$. Результати досліджень наведено в табл. 1. Дані, наведені в цій таблиці, показують, що температура повітря на центральній вулиці, незважаючи на те, що є вуличні посадки, більша за температуру відкритого простору на 2,6\%. Це пов'язано $з$ тим, що сумарне альбедо асфальту і стін будинків нижче, ніж альбедо відкритого грунту. Відомо, що чим нижчий коефіцієнт відбиття (альбедо), тим більше тепла випромінює ця поверхня.

Температура серед забудови у всіх випадках виявилася вищою, ніж серед зелених насаджень. Причому різниця температур між виміряною на вулиці й в дендрологічному парку "Олександрія" становить 14,5 \%. Це можна пояснити тим, що в дендрологічному парку "Олександрія" замір температури робили в балці "Лев", де б'ють потужні прохолодні джерела, над балкою $є$ щільний намет крон дуба черешкового (Quercus robus L.) і навіть в найбільшу спеку в цій балці відчувається приємна прохолода.

Треба враховувати, що теплове випромінювання земної поверхні особливо сильне у приземному шарі повітря, тобто саме в тому шарі, в якому перебуває людина. Отже, серед зелених насаджень складаються комфортніші умови для людського організму, ніж на відкритих просторах.

Табл. 1. Різниця температур на різних об'сктах озеленення

\begin{tabular}{|c|c|c|c|c|c|c|}
\hline \multirow{2}{*}{ Показник } & \multicolumn{5}{|c|}{ Точка спостереження } & \multicolumn{4}{|c|}{\begin{tabular}{c} 
Пквер біля \\
\cline { 2 - 7 }
\end{tabular}} & $\begin{array}{c}\text { Дендрологічний } \\
\text { парк "Олександрія" }\end{array}$ & $\begin{array}{c}\text { Парк культури і від- } \\
\text { починку "Шевченка" }\end{array}$ & $\begin{array}{c}\text { Силй } \\
\text { Білоцерківського НАУ }\end{array}$ & $\begin{array}{c}\text { Вулиця } \\
\text { квартал }\end{array}$ & 28,9 & 29,3 & 31,4 & 30,6 \\
\hline Температура повітря & 26,8 & 28,5 & -1.7 & $-1,3$ & $+0,8$ & - \\
\hline $\begin{array}{c}\text { Різниця температур } \\
\text { (абсолютна, }{ }^{\circ} \text { C) }\end{array}$ & -3.8 & -2.1 & $-5,6$ & $-4,2$ & $+2,6$ & - \\
\hline $\begin{array}{c}\text { Різнця температур } \\
\text { (відносна, \%) }\end{array}$ & $-12,4$ & $-6,9$ & & - \\
\hline
\end{tabular}

Як видно з табл. 1, різниця температур повітря на різних об'єктах озеленення залежить від розмірів зеленого масиву. Відповідно до наведених вище показників температури повітря, найбільша різниця температур спостерігається між температурою в масивах (парк, сквер) і дворами та вулицями. Тобто, чим більшим $\epsilon$ деревний масив, тим більшим $\epsilon$ його вплив на температуру повітря. Також варто зазначити, що найбільший вплив на температуру повітря мають стиглі й перестиглі насадження заввишки понад 20 м і дерева зі щільною широкорозкидистою кроною. А таким вимогам найбільше відповідають саме аборигенні види деревних рослин. Так, згідно 3 даними табл. 1, найбільшу різницю температур між замірами на об'єктах озеленення і контролем бачимо саме в дендропарку "Олександрія", який створений переважно з аборигенних видів дерев. Насадження, де проводили заміри температури (Балка лев), створені такими видами: Quercus robus L., Tilia cordata Mill., Acer platanoides L., Acer pseudoplatanus L., Fraxinus excelsior L.

Порівняно $з$ іншими об'єктами озеленення, різниця температур відносно контролю в дендропарку становила $12,7 \%$, тоді як на інших об'єктах цей показник не перевищив 6,9\%. Тобто, великі вікові деревні масиви, створені аборигенними видами, найбільше впливають за зниження температури в літній період.

Як відомо, у більшості парків Лісостепу України кількісно переважають аборигенні види листяних порід. Це пов'язано з тим, що парки створювали здебільшого на базі природних дібров - корінного типу насаджень цієї природної зони.

Рубцов Л. I. (Rubtcov, 1977) вважав, що головними едифікаторами паркових насаджень повинні бути аборигенні деревні рослини лісових насаджень України. Окрім цього, він запровадив поняття фізіономічних груп і типів деревних рослин. Відповідно до його рекомендацій вважаємо, що найдоцільніше використовувати як паркотвірні види з точки зору їх екології, морфології, декоративних якостей групу декоративно-листяних (тіньових) дерев дубового фізіономічного типу. Сюди входять аборигенні види з родів (Quercus L., Fagus L., Carpinus L., Tilia L., Acer L., Ulmus L.). Вони відрізняються від інших рослин щільною округлою кроною. Дерева 3 такою кроною здатні утворювати густі, тіньові насадження, а як солітери надають певній площі 3 насаджень особливо декоративного вигляду. Окрім цього, із групи ясеневих типів до паркотвірних видів доцільно віднести і Fraxinus excelsior L. Усі аборигенні 
види зі зазначених вище родів входять до складу природних дібров України і тому зрозуміло, що вони будуть утворювати стійкі паркові культурфітоценози. Як корінний тип насаджень та традиційний елемент ландшафту Лісостепу діброви можуть стати його головним своєрідним акцентом.

Лунець Л. Б. встановив, що деревні масиви здатні знижувати температуру повітря на певній відстані від узлісь. Своїми дослідженнями він довів, що чим більший зелений масив, тим значніший його вплив на тепловий режим прилеглих територій (Blaivas, 1972). Вплив деревних масивів на температуру прилеглих територій до масивів і відстань, на яку поширюється цей вплив, наведено в табл. 2.

Табл. 2. Перепад температур повітря залежно від відстані від масиву $\left({ }^{\circ} \mathbf{C}\right)$

\begin{tabular}{|c|c|c|c|c|c|}
\hline Pозмір масиву, & \multicolumn{5}{|c|}{ Відстань від масиву, м } \\
\cline { 2 - 6 } га & 25 & 50 & 100 & 150 & 200 \\
\hline 0,1 & 1,0 & 0,6 & 0,3 & - & - \\
\hline 0,5 & 1,4 & 0,8 & 0,3 & 0,1 & 0,1 \\
\hline 3,0 & 2,0 & 1,2 & 0,8 & 0,5 & 0,5 \\
\hline 5,0 & 2,1 & 1,5 & 1,0 & 0,9 & 0,5 \\
\hline
\end{tabular}

Дані табл. 2 дають підстави вважати обгрунтованим прагнення створювати в наших містах і селищах в першу чергу порівняно великі зелені масиви. Урбанізація призводить до того, що в сучасних реаліях повністю, або частково вирубують лісопарки, парки і сквери і навіть міські ліси під нове будівництво. Цього не можна допускати, бо саме великі деревні масиви (парки) зумовлюють найбільші екологічні зміни в населених пунктах, вони забезпечують зелені розриви в міському просторі й є осередком створення комфортних умов для мешканців населених місць.

Висновки. Отже, за результатами проведених досліджень встановлено:

1. Пряму залежність впливу на температурний режим від розмірів парків. Чим більше паркове насадження за площею, тим більша різниця температур між відкритим простором, або вулицею та парком. Вплив насаджень на температурний режим поширюється тим далі на прилеглі території, чим більша площа деревного масиву.

2. Деревні масиви (парки) доцільно створювати з аборигенних видів деревних рослин дубового фізіономічного типу, які мають найбільшу довговічність у місцевих умовах і як наслідок - висоту I величини, щільну крону, велику площу проекції крони, що дає змогу максимально знизити температуру повітря в літню спеку.

\section{Перелік використаних джерел}

Adamenko, V. N. (1975). Klimat bolshikh gorodov. Obninsk. 71 p. [In Russian].

Blaivas, A. M. (1972). Uluchshenie mikroklimata zhilykh territorii. Moscow: TcINIS, 2.35 p. [In Russian].

Blum, H. F. (1954). Effect of sunligth on man. Monographs, v. 2, 8, $230 \mathrm{p}$.

Bobokhidze, N. B. (1965). Zelenye nasazhdeniia i mikroklimat territorii. Gorodskoe khoziaistvo Moskvy, 5, 24-26. Moscow. [In Russian].

Kalitin, N. N. (1935). Osnovy fiziki atmosfery v primenenii $k$ meditcine. Leningrad: Biomedgiz. 276 p. [In Russian].

Klein, W. H. (1947). Calculation of solar radiation and the solar heat flood on man. J. Meteor, 5, 123-128.

Kucheriavyi, V. P. (2008). Ozelenennia naselenykh mists: pidruchnyk. Lviv: Svit. 456 p. [In Ukrainian].

Landsberg, G. E. (1983). Klimat goroda. (Trans. from English). Leningrad: Gidrometeoizdat. 248 p. [In Russian].

Luntc, L. B. (1974). Gorodskoe zelenoe stroitelstvo. Moscow: Stroiiztat. 275 p. [In Russian].

Rodychkyn, Y. D. (1977). Chelovek, sreda, otdblkh. Kyiv: Budivelnyk. 160 p. [In Ukrainian].

Rubtcov, L. I. (1977). Derevia i kustarniki v landshaftnoi arkhitekture. Kyiv: Nauk. dumka. 272 p. [In Russian].

В. П. Масальский1, С. И. Кузнецов 2

${ }^{1}$ Белоиерковский национальный аграрный университет, г. Белая Церковь, Украина ${ }^{2}$ Национальная академия руководящих кадров культуры и искусства, г. Киев, Украина

\section{ВЛИЯНИЕ ПАРКОВЫХ НАСАЖДЕНИЙ НА ТЕМПЕРАТУРНЫЙ РЕЖИМ УРБАНИЗИРОВАННОЙ СРЕДЫ}

Представлены результаты исследований по влиянию городских насаждений на температурный режим урбанизированной среды. Установлено, что разница температур воздуха на различных объектах озеленения зависит от размеров зеленого массива; чем больше древесный массив, тем больше его влияние на температуру воздуха. Также следует отметить, что наибольшее влияние на температуру воздуха имеют спелые насаждения высотой более 20 м и деревья, имеющие плотную раскидистую крону. Таким требованиям наиболее соответствуют именно аборигенные виды древесных растений. По сравнению с другими объектами озеленения, разница температур по отношению к контролю, в дендропарке составляла $12,7 \%$, в то время как на других объектах этот показатель не превысил 6,9 \%, то есть большие древесные массивы, созданные аборигенными видами, оказывают наибольшее влияние на снижение температуры в летний период. По результатам проведенных исследований установлена прямая зависимость влияния размеров парков на температурный режим. Чем больше древесный массив по площади, тем больше разница температур между парком и открытым пространством или улицей. Доказано, что древесные массивы (парки) целесообразно создавать из аборигенных видов декоративно-лиственной (теневой) группы дубового типа. Отмечено, что чем больше площадь древесного массива, тем дальше распространяется влияние насаждений на температурный режим прилегающей территории.

Ключевые слова: урбанизация; комфортные условия; микроклимат; температурный режим; тепловосприятие; аборигенные виды.

V. P. Masalskiy ${ }^{1}$, S. I. Kuznetsov ${ }^{2}$

${ }^{1}$ Bila Tserkva National Agrarian University, Bila Tserkva, Ukraine ${ }^{2}$ National Academy of Cultural and Arts Management, Kiev, Ukraine

\section{THE IMPACT OF PARK PLANTINGS ON THE TEMPERATURE REGIME} OF THE URBANIZED ENVIRONMENT

Under the growing process of urbanization, the impact of plantations on the temperature regime, as well as the development of proposals on improving this indicator in the urban environment, it is extremely relevant for creating comfortable conditions. Plantings are known to reduce the temperature. Our study is aimed at setting the temperature difference within the city on different landscape objects. The measurements were carried out within one city (Bila Tserkva) at the same time in 5 landscape sites, different 
in the area. For control, the temperature measurements were carried out in open space (on the field) at $0.3 \mathrm{~km}$ from plantations. Electronic thermometers with $0.1^{\circ} \mathrm{C}$ scale were used for measurements. Air temperature difference at different objects of planting is found to depend on the size of the green mass - the larger the tree mass is, the greater is its effect on the air temperature. It should also be noted that the greatest impact on the air temperature is caused by ripe and overgrown plantations with a height of more than $20 \mathrm{~m}$ and a dense broad crown. It is native species of woody plants that meet these requirements most of all. Compared with other objects of planting, the temperature difference in the arboretum was $12.7 \%$, in relation to the control, while at other objects this figure did not exceed $6.9 \%$. That is, large, old trees represented by aboriginal species have the greatest effect on lowering the temperature in the summer. According to the results of the research, direct dependence of parks influence on the temperature regime was established. The larger the park space by area is, the bigger the difference between open space is, or street and park. It is proved that wooden arrays (parks) are expedient to form with aboriginal species of tree plants. It is noted that the bigger the area of a wood mass is, the farther the plantations influence the temperature regime of the adjoining territory extends.

Keywords: urbanization; comfortable conditions; microclimate; temperature regime; thermal perception. 